\title{
Macrocalyxin A inhibits proliferation and induces apoptosis of $t(8 ; 21)$ leukemia cells through mitochondrial signaling pathways and regulates AML-ETO mRNA expression
}

\author{
ZHENNI WANG ${ }^{1}$, YAPING LV ${ }^{2}$, JUN XIA ${ }^{1}$, HAO SHI $^{2}$, WEIZHONG WANG $^{1}$ and YONGLIE ZHOU ${ }^{1}$ \\ ${ }^{1}$ Clinical Laboratory Center, Zhejiang Provincial People's Hospital; ${ }^{2}$ College of Pharmacy, \\ Zhejiang University of Technology, Hangzhou, Zhejiang 310014, P.R. China
}

Received June 22, 2014; Accepted April 10, 2015

DOI: $10.3892 / \mathrm{mmr} .2015 .3855$

\begin{abstract}
Progress in the last decade has improved the treatment of acute myeloid leukemia (AML); however, the treatment of AML is also demanding and better treatments are required. The present study aimed to examine the antiproliferative and proapoptotic effects of macrocalyxin A (MA), a novel deterpenid compound, on AML cells. It was identified that MA significantly inhibits kasumi-1 cell proliferation in a time- and dose-dependent manner. Furthermore, low concentrations of MA were able to induce kasumi-1 cell differentiation; however, high concentrations of MA induced kasumi-1 cell apoptosis. MA was also able to increase the expression of mitochondrial membrane protein in a dose-dependent manner while the $\Delta \Psi \mathrm{m}$ was reduced. Additionally, Bad expression in kasumi-1 cells was increased when treated with MA, indicating that the intrinsic apoptotic pathway may be important in MA-induced kasumi-1 cell apoptosis, where the mitochondrial permeability transition pore is opened and the $\Delta \Psi \mathrm{m}$ is reduced. In addition, it was demonstrated that AML-ETO mRNA may also be important in MA-induced apoptosis.
\end{abstract}

\section{Introduction}

Acute myeloid leukemia (AML) is a clonal disease characterized by the proliferation and accumulation of myeloid progenitor cells in the bone marrow, which ultimately leads to hematopoietic failure (1). Chromosome translocations are frequently present in AML and are important in leukemia development (2). Furthermore, 5-10\% of all patients with AML have the $\mathrm{t}(8 ; 21)$ abnormality, which can generate the AML-ETO fusion oncoprotein blocking myeloid cell differentiation and apoptosis (3-5). The prognosis of elderly patients with AML is

Correspondence to: Professor Yonglie Zhou, Clinical Laboratory Center, Zhejiang Provincial People's Hospital, 158 Shangtang Road, Hangzhou, Zhejiang 310014, P.R. China

E-mail: zhouyonglievip@163.com

Key words: macrocalyxin A, kasumi-1 cell, apoptosis, AML-ETO poor, with a median survival of 4-7 months despite intensive chemotherapy (6), and the 5-year survival ratio of patients with AML that are $<60$-years old is only $30-45 \%(7,8)$. Despite the fact that there have been several practice-changing developments in the diagnosis and treatment of AML, chemotherapy remains one of the most extensively used methods. However, increased tumor cell resistance and the increased drug toxicity provides problems with current chemotherapeutic agents for AML $(9,10)$. Therefore, identification and development of novel drugs remains important.

Chinese herbal medicines, which have been widely found to inhibit proliferation, induce apoptosis, suppress angiogenesis, retard metastasis and enhance chemotherapy, exhibit anticancer potential in vitro and in vivo (11-15). For example, $\beta$-elemene, a compound isolated from Curcuma, exerts anticancer potential and is used as an innovative drug treatment (12). Additionally, oridonin was also a diterpenoid isolated from the isodon plant Rabdosia rubescens (Hemsl.) Hara (Donglingcao), which demonstrated anticancer activity in different tumors, such as Ehrlich ascites carcinoma, sarcoma-180 solid tumor or t $(8 ; 21)$ AML cells (16).

Macrocalyxin A (MA), a deterpenid compound (Fig. 1), was purified from the other isodon plant Rabdosia macrocalyx (Dunn) Hara, which is widely used in jaundice and acute hepatitis, acute cholecystitis and other inflammatory diseases in Chinese medicine. In the present study, using this novel deterpenid compound, it was demonstrated that MA can reduce the viability and enhance apoptosis in AML cells, which may ascribe to the induction of apoptosis by upregulation of $\mathrm{Bad}$, and open the mitochondrial permeability transition pore and reduce $\Delta \Psi \mathrm{m}$. Furthermore, AML-ETO mRNA may also be important in MA-induced apoptosis. In conclusion, the synthesis of a novel drug that, by virtue of its initial assessments, promises to be an effective anticancer agent against AML.

\section{Materials and methods}

$M A$. MA with a purity of $\leq 99 \%$ was provided by Mrs. Ya-Ping Lv (Zhejiang Technology University, Hangzhou, China; Fig. 1), a stock solution was dissolved in dimethyl slufoxide (DMSO; Sigma Aldrich, Carlsbad, CA, USA) at $5 \mathrm{mg} / \mathrm{ml}$ and stored 
at $-80^{\circ} \mathrm{C}$. Then MA was added to the cell culture medium at the different concentrations $(0,4,8,12$ and $16 \mu \mathrm{g} / \mathrm{ml})$.

Cell culture and morphology observation. The following human cell lines (obtained from Zhejiang University, Hangzhou, China) were used: kasumi-1 AML leukemia cells with $\mathrm{t}(8 ; 21)$ translocation, and NB4 and HL60 acute promyelocytic leukemia cells. These cells were cultured at $37^{\circ} \mathrm{C}$ with 5\% $\mathrm{CO}_{2}$ in RPMI-1640 medium (Gibco-BRL, Carlsbad, CA, USA) and supplemented with $10 \%$ heat-inactivated fetal calf serum (Gibco-BRL). Cell viability was detected by propidium iodide (PI; Bender Medsystems, Vienna, Austria) staining with flow cytometry. For morphological observation, cells were observed under light microscopy with Wright's staining (Solarbio, Shanghai, China) and Hoechst 33258 fluorescence staining (Sigma-Aldrich). To evaluate the apoptotic activity of kasumi-1 cells, Hoechst-33258 and Wright's staining were used to observe changes in the cell nucleus. The kasumi- 1 cells $\left(5 \times 10^{5}\right.$ cells in $\left.2 \mathrm{ml}\right)$ were seeded in 6 -well plates overnight and exposed to increasing concentrations of MA for 24 and $48 \mathrm{~h}$. The cells for Hoechst-33258 staining were fixed with methanol:glacial acetic acid (3:1) for 5 min at $4^{\circ} \mathrm{C}$ and incubated with Hoechst-33258 $(5 \mu \mathrm{g} / \mathrm{ml})$ for 15 min after washing with phosphate-buffered saline (PBS). Then the cells were observed under a fluorescence microscope (Nikon Y-THS, Nikon, Tokyo, Japan). The cells for Wright's staining were stained with Wright A and B staining (Solarbio) for $10 \mathrm{~min}$ and observed under a light microscope (Olympus CHA; Olympus, Tokyo, Japan).

Cell proliferation assay. Briefly, cells were seeded into 96-well plates at 30,000-40,000 cells/well and treated with MA (4-16 $\mu \mathrm{g} / \mathrm{ml})$ for 24 and $48 \mathrm{~h}$. Subsequently, the cells were incubated at the different time points with $10 \mu 1$ 3-[4,5-dimethylthiazol-2-yl]-2,5-diphenyltetrazolium bromide (MTT; $10 \mathrm{mg} / \mathrm{ml}$; Sigma-Aldrich) at $37^{\circ} \mathrm{C}$ for $4 \mathrm{~h}$. After the medium was aspirated, the formazan crystals were dissolved in $150 \mu$ l DMSO (Sigma-Aldrich). Subsequently, the absorbance was measured at $570 \mathrm{~nm}$ using a spectrophotometer (Rayto, Shenzhen, China).

Flow cytometric assays for Annexin-V/PI and mitochondrial transmembrane potentials. To assess the early apoptosis of treated cells, an Annexin-V assay was performed on a Navios flow cytometer (Beckman Coulter, Miami, FL, USA) according to instructions provided in the Annexin-V kits (Bender Medsystems). In brief, cells were resuspended in $1 \mathrm{X}$ Annexin $\mathrm{V}$ binding buffer at a final concentration of $1 \times 10^{6}$ cells $/ \mathrm{ml}$. Subsequently, $5 \mu$ l fluorescein isothiocyanate (FITC)-Annexin V and $10 \mu \mathrm{l}$ PI were added to a $100 \mu \mathrm{l}$ cell suspension with a cell concentration of $1 \times 10^{6}$ cells $/ \mathrm{ml}$. The mixture was incubated for $15 \mathrm{~min}$ in the dark at room temperature and detected by flow cytometry. The mitochondrial $\Delta \Psi$ m was also determined using flow cytometry. Briefly, kasumi-1 cells were treated with different concentrations (4, 8,12 and $16 \mu \mathrm{g} / \mathrm{ml}$ ) of MA for $24 \mathrm{~h}$, then washed with PBS, $\sim 2 \times 10^{6}$ cells were incubated with $10 \mu \mathrm{g} / \mathrm{ml}$ rhodamine 123 (RH123, Sigma-Aldrich) at $37^{\circ} \mathrm{C}$ for $30 \mathrm{~min}$. Then the cells were washed with PBS and stained with $50 \mu \mathrm{g} / \mathrm{ml}$ PI. The fluorescence intensity was measured by flow cytometry.

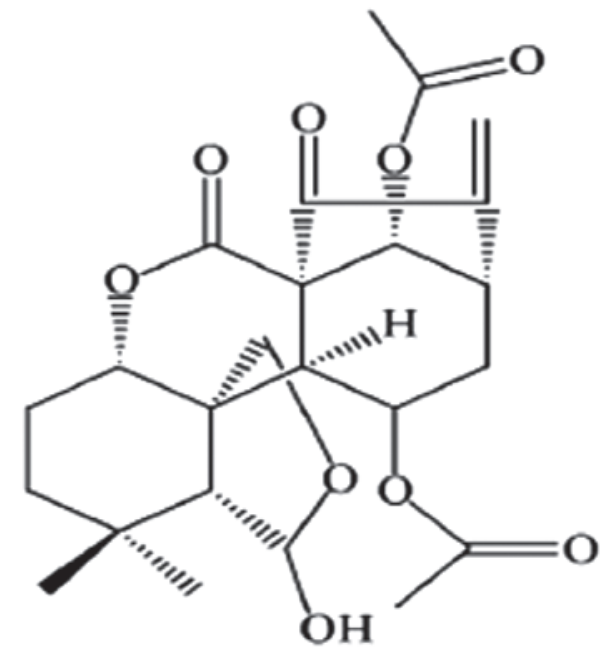

Figure 1. Structure of macrocalyxin A.

Flow cytometric assays for nuclear DNA content distribution. For the distribution of nuclear DNA content, cells treated with MA were harvested, rinsed and washed in PBS, then cells were treated under instructions of the DNA-Prep kit (Beckman Coulter, Miami, FL, USA) and flow cytometry was conducted. All the data were collected and analyzed by muticycle software version 6-16-03-F32 (Beckman Coulter).

Reverse transcription-quantitative polymerase chain reaction (RT-qPCR) analysis. RT-qPCR was performed to measure the expression of AML-ETO. Briefly, total RNA was extracted from cells with TRIzol reagent (Invitrogen Life Technologies, Carlsbad, CA, USA) under the manufacturer's instructions. Then $1 \mu \mathrm{g}$ total RNA was reverse-transcribed using Invitrogen Superscript II reverse transcriptase (Invitrogen Life Technologies, Waltham, MA, USA) and the first strand complimentary DNA synthesis was performed using SuperScript II RT (Invitrogen Life Technologies). Then the qPCR was performed using the SYBR Green PCR master mix (Takara Bio Inc., Otsu, Japan) in the 7500 ABI Prism (Applied Biosystems, Foster City, CA, USA), and the reaction conditions were as follows: $50^{\circ} \mathrm{C}$ for $2 \mathrm{~min}, 95^{\circ} \mathrm{C}$ for $10 \mathrm{~min}$, then 40 cycles of $95^{\circ} \mathrm{C}$ for $15 \mathrm{sec}$ followed by $60^{\circ} \mathrm{C}$ for $1 \mathrm{~min}$. The melt analysis was performed by increasing the temperature from $65-95^{\circ} \mathrm{C}$. The AML-ETO gene was normalized to the expression of the housekeeping gene $\beta$-actin. The primer sequences were as follows: AML-ETO, forward 5'-GTCTTCACAAACCCA CCGCAAG-3', and reverse 5'-GTCAGCCTAGATTGCGTC TTCA-3'; $\beta$-actin, forward 5'-AAGGAGCCCCACGAGAAA AAT-3', and reverse 5'-ACCGAACTTGCATTGATTCCAG-3'. The relative amount of AML-ETO mRNA level was calculated as the average $2-\Delta \mathrm{Ct}$ where $\Delta \mathrm{Ct}=\mathrm{Ct}-\mathrm{Ct} \beta$-actin.

Western blot analysis. In order to determine the potential mechanism underlying the effects of MA on kasumi-1 cell activity, protein expression of relative genes was measured by western blot analysis. Briefly, cells were harvested, washed and lysed with lysis buffer $(62.5 \mathrm{mM}$ Tris- $\mathrm{HCl}, \mathrm{pH} 6.8 ; 2 \%$ SDS, $100 \mathrm{mM}$ DTT and $10 \%$ glycerol), cell lysates were centrifuged at $25,000 \mathrm{xg}$ for $15 \mathrm{~min}$ at $4^{\circ} \mathrm{C}$, then proteins in the 
A

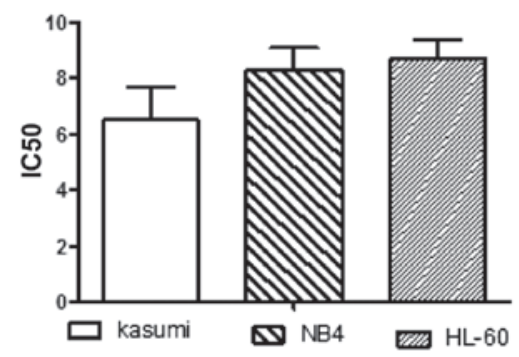

C

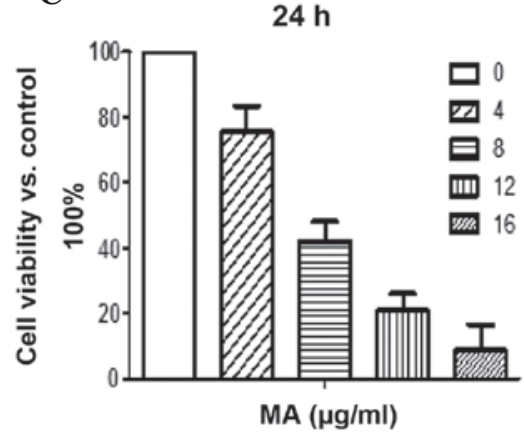

B

Time-dependent manner

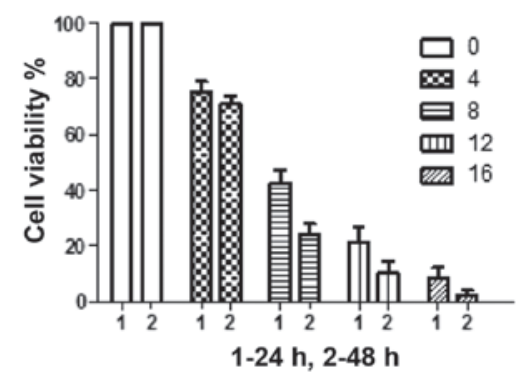

D

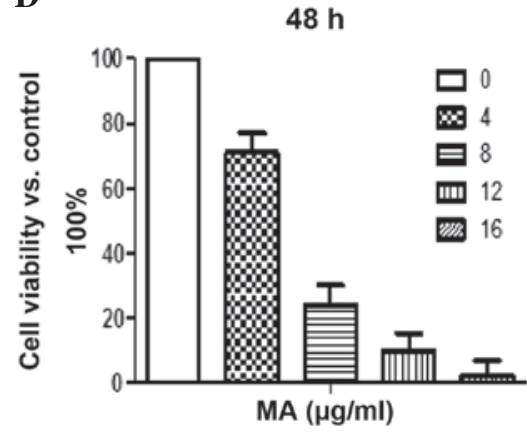

Figure 2. MA inhibits cell proliferation in leukemia cells. (A) Kasumi-1 cells were cultured with MA (4-16 $\mu \mathrm{g} / \mathrm{ml})$, after $24 \mathrm{~h}$ cell viability was observed by PI staining and flow cytometry. (B) Kasumi- 1 cells cultured with MA (4-16 $\mu \mathrm{g} / \mathrm{ml})$, after $48 \mathrm{~h}$, cell viability was determined by PI staining by flow cytometry. (C) Kasumi-1 cells cultured with MA (4-16 $\mu \mathrm{g} / \mathrm{ml})$, after $24 \mathrm{~h}$ and $48 \mathrm{~h}$, MA significantly inhibited the proliferation of kasumi-1 cells, and the cell viability were time and dose dependent. (D) $\mathrm{IC}_{50}$ obtained from MTT assay in kasumi-1, HL-60 and NB4 cells treated with MA for $24 \mathrm{~h}$ respectively. MA, macrocalyxin A; PI, propidium iodide.
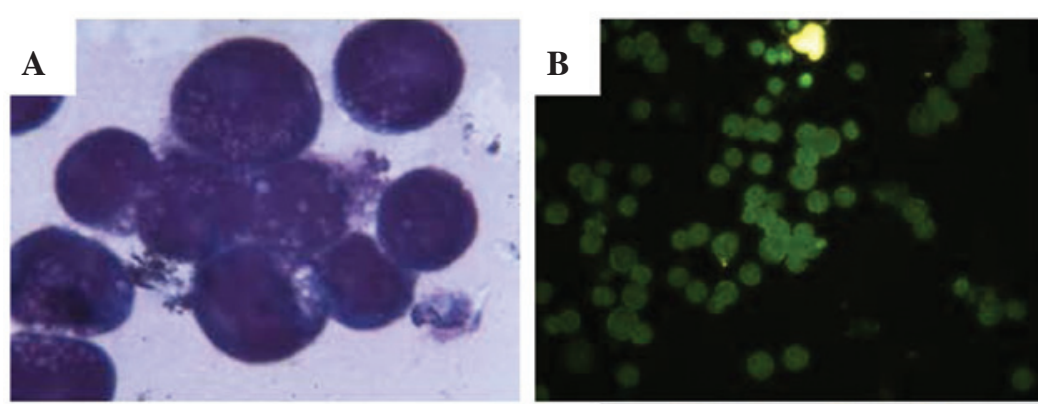

C

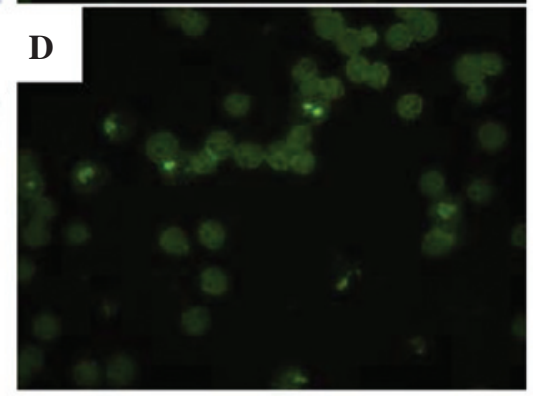

Figure 3. Morphological observation of MA treatment in kasumi-1 cells. (A) Wright's staining for the control kasumi-1 cells without MA treatment (magnification, x1,000). (B) Hoechst-33258 fluorescence staining for the control kasumi-1 cells without MA treatment (magnification, x200). (C) Wright's staining for the Kasumi-1 cells treated with $4 \mu \mathrm{g} / \mathrm{ml}$ MA for $24 \mathrm{~h}$ (magnification, $\mathrm{x} 1,000$ ). In certain apoptotic cells, a shrinking cytoplasm, condensed chromatin and nuclear fragmentation were observed. (D) Hoechst-33258 fluorescence staining for the Kasumi-1 cells treated with $4 \mu \mathrm{g} / \mathrm{ml}$ MA for $24 \mathrm{~h}$ (magnification, x200). MA, macrocalyxin A.

supernatant were quantified by the bicinchoninic acid method according to the manufacturer's instructions (Pierce, Rockford, IL, USA), protein lysates $(20 \mu \mathrm{g})$ were resolved on a $10-15 \%$ SDS-polyacrylamide gel electrophoresis, and transferred to a polyvinylidene difluoride membrane (Whatman, Maidstone, UK), the following antibodies were used: Rabbit monoclonal antibody (mAb) pro-caspase-3 (1:1,000; cat. no. 9665), rabbit polyclonal antibody (pAb) Bax (1:1,000; cat. no. 2774), NF-кB 
Table I. Effect of MA on the early apoptosis of kasumi-1 (mean values \pm standard deviation).

$\%$ of cells following treatment with MA

\begin{tabular}{lrrrrr}
\cline { 2 - 5 } Cells & \multicolumn{1}{c}{ Control } & $4 \mu \mathrm{g} / \mathrm{ml}$ & $8 \mu \mathrm{g} / \mathrm{ml}$ & $12 \mu \mathrm{g} / \mathrm{ml}$ & $16 \mu \mathrm{g} / \mathrm{ml}$ \\
\hline Annexin $\mathrm{V}^{+} / \mathrm{PI}^{-}$ & $0.3 \pm 1.5$ & $8.4 \pm 1.3^{\mathrm{a}}$ & $15.7 \pm 2.1^{\mathrm{a}}$ & $28.4 \pm 1.6^{\mathrm{a}}$ & $33.2 \pm 3.2^{\mathrm{a}}$ \\
Annexin $\mathrm{V}^{+}$ & $0.66 \pm 1.5$ & $13.0 \pm 1.0^{\mathrm{a}}$ & $17.8 \pm 1.4^{\mathrm{a}}$ & $59.4 \pm 2.3^{\mathrm{a}}$ & $67.3 \pm 2.6^{\mathrm{a}}$ \\
Sub G1 phase & $1.11 \pm 1.4$ & $7.11 \pm 1.7^{\mathrm{a}}$ & $11.4 \pm 1.6^{\mathrm{a}}$ & $44.1 \pm 2.1^{\mathrm{a}}$ & $57.8 \pm 2.4^{\mathrm{a}}$
\end{tabular}

PI, propidium iodide; MA, macrocalyxin A.

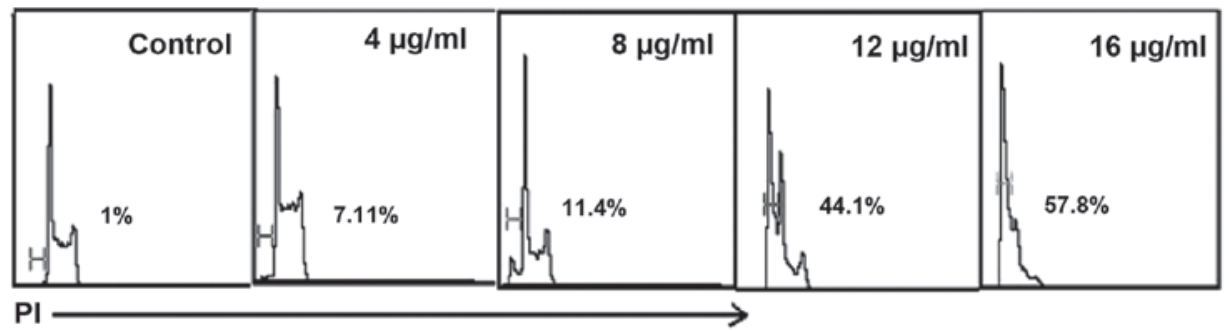

Figure 4. Apoptotic effects of MA on kasumi-1 cells. A significant increase in the number of cells in the sub-G1 phase was observed following treatment with $4,8,12$ and $16 \mu \mathrm{g} / \mathrm{ml} \mathrm{MA}$ for $24 \mathrm{~h}$.

A

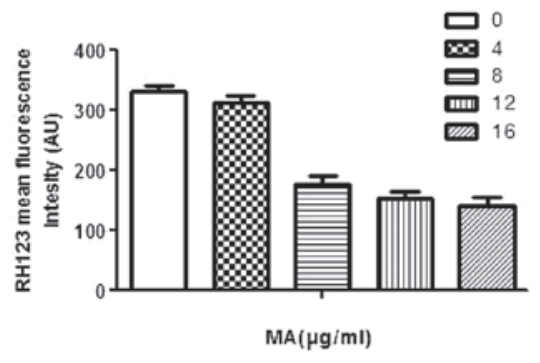

B

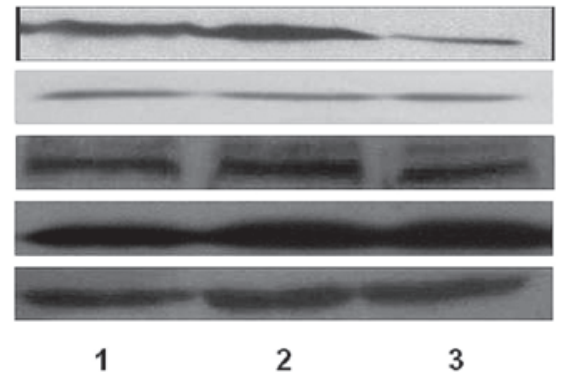

Pro-caspase 3

$\mathrm{Bcl}-2$

Bax

Bad

Actin

Figure 5. MA induced apoptosis through caspase-3 and collapse of $\Delta \psi \mathrm{m}$ induced by upregulation bad/bcl-2. (A) Mean fluorescence intensity of RH123 was decreased with MA treatment. (B) Effect of MA on the protein expression of Bcl-2, bax, bad and pro-caspase3. Lane 1, treatment with $0 \mu \mathrm{g} / \mathrm{ml} \mathrm{MA}$; lane 2, treatment with $4 \mu \mathrm{g} / \mathrm{ml} \mathrm{MA}$; and lane 3, treatment with $8 \mu \mathrm{g} / \mathrm{ml} \mathrm{MA}$. MA, macrocalyxin A; RH123, rhodamine 123.

rabbit pAb (1:1,000; cat. no. 3034), rabbit mAb Bad (1:1,000; cat. no. 9239), rabbit pAb ETO (1:1,000; cat. no. 4498), which were all purchased from Cell Signaling Technology (Danvers, MA, USA). The mouse mAb Bcl-2 (1:250; cat. no. sc-7382), mouse $\mathrm{mAb} \beta$-actin $(1: 1,000$; cat. no. sc-47778), which were purchased from Santa Cruz Biotechnology, Inc. (Santa Cruz, CA, USA). Additionally, corresponding horseradish peroxidase-conjugated secondary antibodies were purchased from the Cell Signaling Technology. The band intensities were measured using densitometry by means of the quantity one version software (Bio-Rad, Hercules, CA, USA).

Statistical analysis. Quantitative data are presented as the mean \pm standard deviation. Statistical significance was determined by means of the two-tailed Student's t-test. Statistical analysis was performed using SPSS 15.0 (SPSS, Inc., Chicago, IL, USA). All results were obtained from three separate experiments. $\mathrm{P}<0.05,0.01$ and 0.001 were considered to indicate a statistically significant difference.

\section{Results}

MA suppresses AML cell proliferation. To evaluate the effect of MA on the viability of AML cells, three AML cell lines (NB4, HL-60 and kasumi-1) were treated with MA at different concentrations $(4,8,12$ and $16 \mu \mathrm{g} / \mathrm{ml})$ and their viability was detected by an MTT assay. The MTT assay showed that MA inhibited the proliferation of the three cell lines in a dose-dependent manner at different time points, and the half maximal inhibitory concentration $\left(\mathrm{IC}_{50}\right)$ was measured in those cells with MA at concentrations of $5-9 \mu \mathrm{g} / \mathrm{ml}$ for $24 \mathrm{~h}$, respectively, where the $\mathrm{IC}_{50}$ values were $6.5,8.34$ and $8.76 \mu \mathrm{g} / \mathrm{ml}$ in the kasumi-1, NB4 and HL-60 cells, respectively (Fig. 2A). Additionally, it was observed that MA significantly inhibited the proliferation of kasumi- 1 cells, and this effect occurred in a time- and dose-dependent manner (Fig. 2B), and the average growth inhibition percentages were 25,58 , 76 and $92 \%$ following treatment with $4,8,12$ and $16 \mu \mathrm{g} / \mathrm{ml}$ MA, respectively, for $24 \mathrm{~h}$ (Fig. 2C). Thus, following $48 \mathrm{~h}$ of 
A

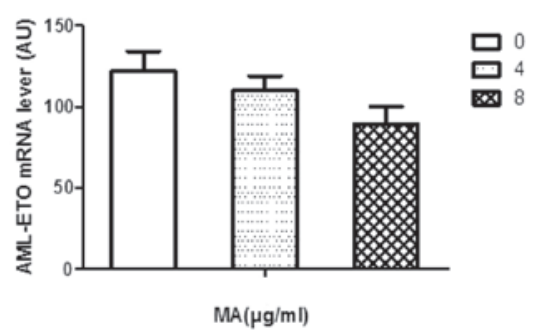

B

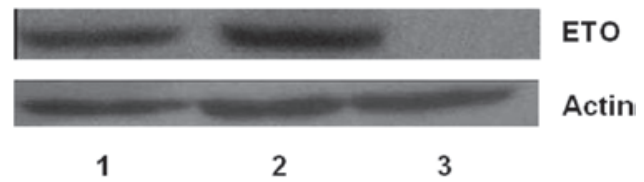

Figure 6. Effects of MA on AML-ETO fusion gene and protein. (A) MA inhibits expression of AML-ETO mRNA in kasumi-1 cells compared with control cells. (B) Effect of MA on the protein expression of ETO. Lane 1, treatment with $0 \mu \mathrm{g} / \mathrm{ml} \mathrm{MA}$; lane 2, treatment with $4 \mu \mathrm{g} / \mathrm{ml} \mathrm{MA}$; and lane 3 , treatment with $8 \mu \mathrm{g} / \mathrm{ml}$ MA. MA causes a degradation of AML-ETO protein in MA-treated kasumi-1 cells. MA, macrocalyxin A.

treatment, $8 \mu \mathrm{g} / \mathrm{ml}$ MA induced $79 \%$ cell death and $16 \mu \mathrm{g} / \mathrm{ml}$ MA resulted in $98 \%$ cell death (Fig. 2D). These results show that kasumi-1 cells are more sensitive to MA treatment than NB4 and HL-60 cells. Therefore, kasumi-1 cells were used in the majority of the experiments. Furthermore, according to viable cell numbers of treated cells against numbers of untreated cells under light microscopy, the inhibition rates were calculated and measured by an MTT assay.

MA induces the apoptosis of kasumi-1 cells. To confirm whether the growth inhibition of kasumi-1 cells was caused by apoptosis, kasumi-1 cells with MA treatment were observed under a microscope, when the kasumi-1 cells were treated with MA, the appearance of morphological characteristics of apoptosis, such as shrinking cytoplasm, condensed chromatin and nuclear fragmentation was observed (Fig. 3). Additionally, the Annexin V-FITC/PI double-staining kit was used to detect the effect of MA on apoptosis. It was found that following treatment with MA at different concentrations for $12 \mathrm{~h}$, the early apoptosis rates of kasumi-1 cells synchronized with MA concentrations, reaching $0.3,8.4,15.7,28.4,33.2 \%$ at concentrations of 0,4 , 8,12 and $16 \mu \mathrm{g} / \mathrm{ml}$ (Table I). Thus, the apoptosis effect with MA in kasumi-1 cells occurred in a dose-dependent manner. Additionally, the cell cycle of kasumi-1 cells was also detected with MA at 4, 8, 12, $16 \mu \mathrm{g} / \mathrm{ml}$ for $24 \mathrm{~h}$. No significant change was identified in the G1, S and G2/M proportion in kasumi-1 cells treated with MA; however, the sub-G1 cells were increased in a dose-dependent manner (Fig. 4, Table I). These results indicated that MA could induce the apoptosis of kasumi-1 cells.

MA-induced apoptosis is associated with caspase-3 and collapse of $\Delta \psi m$ through upregulation of bad/bcl-2. The mitochondria pathway is an important intrinsic pathway in apoptosis, and RH123 was first used to measure the $\Delta \psi \mathrm{m}$ in cells. In order to understand the underlying mechanism in the apoptosis effect of MA, the effects of MA on $\Delta \psi \mathrm{m}$ were evaluated with RH123 staining. The results showed that untreated living cells were strongly stained by RH123 when exposed to MA at 4, 8, 12, $16 \mu \mathrm{g} / \mathrm{ml}$, the mean fluorescence intensity of RH123 in kasumi-1 cells was significantly decreased, suggesting that the cell membrane potential was decreased in a dose-dependent manner (Fig. 5A). Furthermore, to identify whether MA damaged mitochondria via bcl-2, bad, bax proteins, their expression levels were investigated in kasumi-1 cells when incubated with MA for $24 \mathrm{~h}$ at $4 \mu \mathrm{g} /$ $\mathrm{ml}$ concentration. The results of western blot showed that the protein expression of Bad was increased in a dose-dependent manner, whereas no significant change in the expression of bcl-2 and bax was observed. Additionally, in parallel to $\Delta \psi \mathrm{m}$, procaspase-3 was decreased. These results suggested that MA induced cell apoptosis through the caspase-dependent mitochondrial pathway (Fig. 5B).

MA induces degradation of AML-ETO oncoprotein in association with blockade of AML-ETO mRNA. AML1-ETO, which is generated by the chromosomal translocation $\mathrm{t}(8 ; 21)(\mathrm{q} 22 ; \mathrm{q} 22)$, has been shown to lead to the abnormal proliferation of leukemic cells, and the arrest of cell division and differentiation. To identify whether MA affects the AML cells through this target, RT-qPCR analysis for expression of AML-ETO mRNA was conducted. It showed that the expression levels of AML-ETO were significant lower in the kasumi-1 cells with MA treatment than in untreated cells (Fig. 6A). Furthermore, to further verify this MA-mediated AML-ETO degradation, anti-ETO antibodies were used in western blots. It was found that MA degraded the AML-ETO protein in kasumi-1 cells when treated with MA for $24 \mathrm{~h}$ at 4 , $8 \mu \mathrm{g} / \mathrm{ml}$ (Fig. 6B).

\section{Discussion}

In recent years, it has been reported that a number of natural products isolated from Chinese herbs have been found to inhibit proliferation, induce apoptosis, suppress angiogenesis, retard metastasis and enhance chemotherapy, exhibiting anticancer potential in vitro and in vivo (12). MA (MA), a deterpenid compound purified from Rabdosia macrocalyx (Dunn) Hara, was been widely used in jaundice and acute hepatitis, acute cholecystitis and other inflammatory diseases in Chinese medicine. In this study, the results of the MTT assay demonstrated that MA can inhibit the proliferation of kasumi-1 cells in a dose- and time-dependent manner. Moreover, results of Annexin V/PI staining, nuclear DNA content distribution, DNA gel electrophoresis and morphology analysis suggested that MA can induce apoptosis of kasumi-1 cells.

The extrinsic and intrinsic apoptotic pathways are two classic cell apoptosis routes. The mitochondrial membrane exhibits an important role in the intrinsic pathway and disruption of the intrinsic pathway is common in cancer cells $(17,18)$. During apoptosis, the permeability of the mitochondrial membrane increases, leading to the loss of membrane potential and release of cytochrome $c$ in the cytosol. Released cytochrome $c$ binds to Apaf-1, which activates caspase-9, triggering caspase-3 activation and resulting in the cleavage of PARP (19). The mitochondrial death pathway is controlled by members of the Bcl-2 family, which exhibit a central regulatory role to 
decide the fate of the cells via interactions between pro- and anti-apoptotic members $(19,20)$. During apoptosis, Bcl-2 family pro-apoptotic proteins can translocate to the outer membrane of mitochondria, promote the release of pro-apoptotic factors and induce apoptosis. Conversely, Bcl-2 family anti-apoptotic proteins sequester in the mitochondria inhibiting the release of pro-apoptotic factors and preventing apoptosis. After receiving apoptosis signals, whether or not the cells can survive depends on the ratio of anti-apoptotic/pro-apoptotic Bcl-2 family. The cell dies if the Bad family is dominant, and survives when Bcl-2 is dominant $(17,21)$. In the present study, the results of western blot analysis showed that cells treated with MA increased the level of the pro-apoptotic protein Bad, while the level of the anti-apoptotic protein $\mathrm{Bcl}-2$ was not markedly changed. Furthermore, a marked attenuation of $\Delta \Psi \mathrm{m}$ occurred in cells exposed to MA in a concentration-dependent manner. In addition, it was also observed that MA increased the caspase-3 activity. These results showed that the apoptosis effect of MA in kasumi-1 cells was dependent on the mitochondrial pathway.

The AML-ETO fusion gene is the most frequently mutated gene in AML, and $\sim 46 \%$ of patients with AML exhibit French-America-British (FAB)-M2 morphology (22). The AE fusion protein inhibits transcription of AML1 target genes, activates transcription of apoptotic antagonist $\mathrm{Bcl}-2$, enhances self-renewal of hematopoietic stem/progenitor cells, blocks hematopoietic differentiation and disturbs normal cell proliferation $(22,23)$. Additionally, it has been reported that treatment strategies interfering with $\mathrm{AE}$ oncoprotein in leukemia showed high therapeutic efficacy with low adverse effects. Oridonin, a diterpenoid isolated from the isodon plant, targeted the AML-ETO fusion protein with few adverse effects in patients with $\mathrm{t}(8 ; 21)$ leukemia in vitro and in vivo (16). Eriocalyxin B induces apoptosis of leukemia cells and triggers degradation of AML-ETO in a caspase-3 dependent manner (23). In the present study, the mRNA expression level of AML-ETO and the AML-ETO fusion protein were analyzed. RT-qPCR showed that AML-ETO mRNA levels decreased in a dose-dependent manner, and the fusion protein was also degraded following treatment with MA. To an extent, it was determined that MA affects the biology of AML cells through the AML-ETO target.

In conclusion, the results showed that MA can inhibit kasumi-1 cell proliferation and induce apoptosis. The underlying mechanism may be associated with the intrinsic apoptosis pathway via its upregulation of $\mathrm{Bad}$, which opens the mitochondrial permeability transition pore and reduces $\Delta \Psi \mathrm{m}$. Furthermore, AML-ETO mRNA may also be involved in MA-induced apoptosis.

\section{Acknowledgements}

This study was supported by the Pharmaceutical Administration Research Fund of Zhejiang Province (grant no. 2012ZA017).

\section{References}

1. Ferrara F and Schiffer CA: Acute myeloid leukaemia in adults. Lancet 381: 484-495, 2013.

2. Sabattini E, Bacci F, Sagramoso C and Pileri SA: WHO classification of tumours of haematopoietic and lymphoid tissues in 2008: an overview. Pathologica 102: 83-87, 2010.
3. Peterson LF, Boyapati A, Ahn EY, Biggs JR, Okumura AJ, Lo MC, et al: Acute myeloid leukemia with the 8q22; 21q22 translocation: secondary mutational events and alternative $\mathrm{t}(8 ; 21)$ transcripts. Blood 110: 799-805, 2007.

4. Steffen B, Knop M, Bergholz U, Vakhrusheva O, Rode M, Köhler G, et al: AML1/ETO induces self-renewal in hematopoietic progenitor cells via the Groucho-related amino-terminal AES protein. Blood 117: 4328-4337, 2011.

5. Gardini A, Cesaroni M, Luzi L, Okumura AJ, Biggs JR, Minardi SP, et al: AML1/ETO oncoprotein is directed to AML1 binding regions and co-localizes with AML1 and HEB on its targets. PLoS Genet 4: e1000275, 2008.

6. Quintás-Cardama A, Ravandi F, Liu-Dumlao T, Brandt M, Faderl S, Pierce S, et al: Epigenetic therapy is associated with similar survival compared with intensive chemotherapy in older patients with newly diagnosed acute myeloid leukemia. Blood 120: 4840-4845, 2012.

7. Tallman MS: Novel therapeutic strategies for AML in 2012. Hematology 17 (Suppl 1): 43-46, 2012.

8. Lengfelder E, Hanfstein B, Haferlach C, Braess J, Krug U, Spiekermann K, et al: Outcome of elderly patients with acute promyelocytic leukemia: results of the German Acute Myeloid Leukemia Cooperative Group. Ann Hematol 92: 41-52, 2013.

9. Burnett AK, Hills RK, Milligan DW, Goldstone AH, Prentice AG, McMullin MF, et al: Attempts to optimize induction and consolidation treatment in acute myeloid leukemia: results of the MRC AML12 trial. J Clin Oncol 28: 586-595, 2010.

10. Buchner T, Berdel WE, Haferlach C, Haferlach T, Schnittger S, Muller-Tidow C, et al: Age-related risk profile and chemotherapy dose response in acute myeloid leukemia: a study by the German acute myeloid leukemia cooperative group. J Clin Oncol 27: 61-69, 2009.

11. Kasibhatla S, Jessen KA, Maliartchouk S, Wang JY, English NM, Drewe $\mathrm{J}$, et al: A role for transferrin receptor in triggering apoptosis when targeted with gambogic acid. Proc Natl Acad Sci USA 102: 12095-12100, 2005.

12. Tan W, Lu J, Huang M, Li Y, Chen M, Wu G, et al: Anti-cancer natural products isolated from chinese medicinal herbs. Chin Med 6: 27, 2011.

13. Baumann S, Fas SC, Giaisi M, Muller WW, Merling A, Gülow K, et al: Wogonin preferentially kills malignant lymphocytes and suppresses T-cell tumor growth by inducing PLCgamma1- and Ca2+-dependent apoptosis. Blood 111: 2354-2363, 2008.

14. Ramasamy K, Dwyer-Nield LD, Serkova NJ, Hasebroock KM, Tyagi A, Raina K, et al: Silibinin prevents lung tumorigenesis in wild-type but not in iNOS-/-mice: potential of real-time micro-CT in lung cancer chemoprevention studies. Clin Cancer Res 17: 753-761, 2011.

15. Singh T, Vaid M, Katiyar N, Sharma S and Katiyar SK: Berberine, an isoquinoline alkaloid, inhibits melanoma cancer cell migration by reducing the expressions of cyclooxygenase-2, prostaglandin E 2 and prostaglandin E 2 receptors. Carcinogenesis 32: 86-92, 2011.

16. Zhou GB, Kang H, Wang L, Gao L, Liu P, Xie J, et al: Oridonin, a diterpenoid extracted from medicinal herbs, targets AML1-ETO fusion protein and shows potent antitumor activity with low adverse effects on $t(8 ; 21)$ leukemia in vitro and in vivo. Blood 109: 3441-3450, 2007.

17. Ola MS, Nawaz M and Ahsan H: Role of Bcl-2 family proteins and caspases in the regulation of apoptosis. Mol Cell Biochem 351: 41-58, 2011

18. Hensley P, Mishra M and Kyprianou N: Targeting caspases in cancer therapeutics. Biol Chem 394: 831-843, 2013.

19. von Schwarzenberg K and Vollmar AM: Targeting apoptosis pathways by natural compounds in cancer: marine compounds as lead structures and chemical tools for cancer therapy. Cancer Lett 332: 295-303, 2013

20. Oltersdorf T, Elmore SW, Shoemaker AR, Armstrong RC, Augeri DJ, Belli BA, et al: An inhibitor of Bcl-2 family proteins induces regression of solid tumours. Nature; 435: 677-681, 2005.

21. Czabotar PE, Lessene G, Strasser A and Adams JM: Control of apoptosis by the BCL-2 protein family: implications for physiology and therapy. Nat Rev Mol Cell Biol 15: 49-63, 2014.

22. Licht JD: AML1 and the AML1-ETO fusion protein in the pathogenesis of $\mathrm{t}(8 ; 21)$ AML. Oncogene 20: 5660-5679, 2001.

23. Wang L, Zhao WL, Yan JS, Liu P, Sun HP, Zhou GB, et al: Eriocalyxin B induces apoptosis of $\mathrm{t}(8 ; 21)$ leukemia cells through NF-kappaB and MAPK signaling pathways and triggers degradation of AML1-ETO oncoprotein in a caspase-3-dependent manner. Cell Death Differ 14: 306-317, 2007. 